1. MBBS, MRCP Assistant Professor Indus Medical College, Tando Muhammad Khan.

2. MBBS, MD (Cardiology) Assistant Professor Bilawal Medical College, LUMHS, Jamshoro.

3. MBBS, MRCOG Consultant Gynaecologist South City Hospital, Karachi.

4. MBBS, D.Ophth, PhD.

Senior Lecturer

Department of Anatomy Liaquat University of Medical \& Health Sciences, Jamshoro, Sindh. 5. MBBS, PhD.

Professor

Dow Medical College,

Dow University of Health Sciences, Karachi.

6. MBBS, M.Phil (Anatomy)

Associate Professor

Indus Medical College,

Tando Muhammad Khan.

Correspondence Address:

Dr. Muhammad Yaqoob Shahani

MBBS, D.Ophth, Ph.D

Senior Lecturer

Department of Anatomy

Liaquat University of medical \&

health sciences, Jamshoro, Sindh

doctor_shahani@hotmail.com

Article received on:

08/01/2019

Accepted for publication:

25/05/2019

\section{STUDY ON RED CELL DISTRIBUTION WIDTH, HAEMATOCRIT AND RED BLOOD CORPUSCLE (RBC) INDICES AS EARLY MARKERS FOR THE DETECTION OF CORONARY ARTERY DISEASE: A CASE CONTROL STUDY.}

Shahzeb Rasool Memon', Gul Hassan Brohi'2, Fozia Rasool Memon ${ }^{3}$, Muhammad Yaqoob Shahani ${ }^{4}$, Samreen Memon ${ }^{5}$, Shazia Begum Shahani ${ }^{6}$

ABSTRACT... We tested the hypothesis that Red cell distribution width, Hct, and other red blood corpuscle (RBC) indices are associated with CAD. Hence, we measured RDW, Hct, and other RBC indices in AMI and stable CAD (SCAD) and compared them with age- and sex-matched controls. Objectives: To study the changes in Red cell distribution width and RBC indices in acute myocardial infarction (AMI) and SCAD and compare them with age- and sex-matched controls. Study Design: A comparative study. Setting: Department of Cardiology, Liaquat University Hospital. Period: $1^{\text {st }}$ September 2013 to $28^{\text {th }}$ February 2014. Material \& Methods: 128 subjects (39 AMI patients, 24 SCAD patients and 65 controls). Venous samples from AMI subjects were collected in standardized ethylenediaminetetraacetic acid (EDTA) sample tubes on admission (within $6 \mathrm{~h}$ of chest pain). Using Sysmex KX21-N autoanalyzer, RDW and RBC indices were evaluated within 30 minutes of blood collection. Arterial blood samples were also obtained from stable CAD patients admitted to angiography and routine inspections. There has been no significant difference. Results: In total 128 patients, Mean \pm SD of RDW patients with CAD was $14.12 \pm 1.31 \%)$ as compared to controls (15.62 $\pm 6.51 \%$ ) with insignificant difference ( $p$ value $>0.05$ ). Mean \pm SD of RDW patients with AMI was $14.36 \pm 1.4 \%$ as compared to stable CAD (13.7 $\pm 1.09 \%$ ) and controls (15.62 $\pm 6.51 \%$ ) ( $p$ value $>0.05)$. Mean \pm SD of RDW patients with Hct in patients with CAD was $43.16 \pm 5 \%$ as compared to controls (41.9 $\pm 6.9 \%$ ) with insignificant difference ( $p$ value $>0.05$ ). Conclusions: There was no association between RWD, Hct, and other RBC indices with CAD, AMI, and stable CAD.

Key words: $\quad$ Coronary Artery Disease, Hematocrit, Red Cell Distribution Width.

Article Citation: Memon SR, Brohi GH, Memon FR, Shahani MY, Memon S, Shahani SB. Study on red cell distribution width, haematocrit and red blood corpuscle (RBC) indices as early markers for the detection of coronary artery disease: a case control study. Professional Med J 2019; 26(12):2075-2079. DOI: 10.29309/TPMJ/2019.26.12.3069

\section{INTRODUCTION}

Acute coronary syndromes (ACSs) are a set of early warning signs caused by a plaque rupture and result from the formation of cardiac thrombus. The thrombus leads to partial or complete coronary artery occlusion, leading to myocardial ischemia and numerous clinical manifestations from unstable angina (UA) to acute myocardial infarction (AMI). The distribution width of red blood cells (RDW) is a quantitative measurement of the variability of the circulating erythrocyte size. ${ }^{1}$

This variable and hematocrit levels (Hct) are usually reported throughout the blood, but its use is generally limited to lowering the risk of anemia. ${ }^{2}$
A number of studies have confirmed a strong independent relationship between higher levels of RDW and the risk of death and cardiovascular events in people with previous coronary artery disease $(\mathrm{CAD})$. $^{3-6}$

Several reports have established strong relation between anemia and the risk of death and cardiovascular events in people with CAD. ${ }^{7}$

However, whether RDW and Hct are associated with adverse outcomes in persons without heart failure is unknown. We tested the hypothesis that RDW, Hct, and other RBC indices are associated with CAD. Hence, we measured RDW, Hct, and other red blood corpuscle (RBC) indices in AMI 
and stable CAD (SCAD) and compared them with age- and sex-matched controls.

\section{MATERIALS AND METHODS}

This hospital-based, case-control study was carried out in the department of Cardiology, Liaquat University Hospital to assess whether RWD, Hct, and other RBC indices show variation in the spectrum of CAD from $1^{\text {st }}$ September 2013 to $28^{\text {th }}$ February 2014.

The research procedure was accepted by the hospital's Institute Committee and the patients received written consent. The size of the sample was estimated based on the confidence interval in the pilot study.

Total of 128 patients were selected and divided into three groups for study. Groups $1 \mathrm{~A}$ and $1 \mathrm{~B}$ included CAD patients, and Group 2 included healthy controls Group 1A included AMI intake patients. Group 1B SCAD includes AMI CAD patients 5 weeks ago and angiography without chest pain.

Patients with anemia (hemoglobin $(\mathrm{Hb})<10$ $\mathrm{g} \%)$, polycythemia, liver disease, kidney disease, myeloproliferative complaints, and carcinoma were not included in the study. All patients were recruited from $1^{\text {st }}$ September 2013 to $28^{\text {th }}$ February 2014.

In Group 1A patients before administration of anticoagulants and antiplatelet medications, blood samples were collected within 6 hours when patients reached at casualty into tubes containing ethylenediaminetetraacetic acid (EDTA) that were subsequently diagnosed having AMI.

For measurement of $\mathrm{Hb}$, Hct, mean corpuscular volume (MCV), mean corpuscular $\mathrm{Hb}(\mathrm{MCH})$, $\mathrm{MCH}$ concentration (MCHC), and platelet width distribution (PWD)-standard deviation (SD) and PWD-coefficient of variation (CV), samples were examined with the Sysmex KX21-N automated flow meter within 30 minutes of collection.

Group B blood samples were collected and analyzed on the day of admission. Group C subjects were collected in the ambulatory department for routine checks and their blood samples.

Acute myocardial infarction was identified by increase or decrease cardiac markers like Trop I or CKMB and symptoms of ischemia, changes in ECG, $Q$ waves, loss of viable myocardium and other irregularity. Patients in Group 1B were recognized who had previous history of $\mathrm{AMI}$ at least 5 weeks before. Their symptoms were $Q$ wave in ECG and imaging evidence of new loss of viable myocardium or a new regional wall motion abnormality.

\section{Data Analysis}

The data was entered and analyzed in SPSS version 22.0. All the numerical variables were presented as Mean \pm SD and student "t" test was applied to compare the means between case and control groups. $P$ value less than 0.05 was considered significant level for the comparisons.

\section{RESULTS}

A total of 128 patients were included in the study based on inclusion and exclusion criteria. Out of them 17 were females and 111 patients were males. In group 1A 39 patients were identified by acute myocardial infarction while in Group B there were 24 patients were diagnosed by AMI at least 5 weeks prior admitted for angiography. We did not see any significant difference of age and gender in both groups ( $p$ value $>0.05$ ).

There was no significant increase in RBC count, $\mathrm{Hb}$, hematocrit, $\mathrm{MCV}, \mathrm{MCH}$, and $\mathrm{MCHC}$ in Group 1 when compared to controls. There was no significant decrease in RWD-SD and RWD-CV in Group 1 when compared to controls [Table-I]. There was no significant difference in age, sex, $\mathrm{RBC}$ count, $\mathrm{Hb}$, hematocrit, $\mathrm{MCV}, \mathrm{MCH}, \mathrm{MCHC}$, RWD-SD, and RWD-CV in group analysis between Group 1A, 1B, and 2 [Table-II]. 


\begin{tabular}{|c|c|c|c|c|c|}
\hline & & $\begin{array}{c}\text { Group1, } \\
\text { CAN, } n=63\end{array}$ & $\begin{array}{c}\text { Group 2, } \\
\text { Controls, } n=65\end{array}$ & t Value & P-Value \\
\hline \multicolumn{2}{|l|}{ Age (years) } & $55.14 \pm 9.8$ & $54.46 \pm 8.6$ & 0.417 & 0.677 \\
\hline \multicolumn{2}{|c|}{ Red blood cell $\left(10^{5} \mu \mathrm{L}\right)$} & $4.93 \pm 0.63$ & $4.85 \pm 0.78$ & 0.674 & 0.501 \\
\hline \multicolumn{2}{|c|}{ Hemoglobin' (g\%) } & $13.77 \pm 2.4$ & $13.42 \pm 2.5$ & 0.789 & 0.432 \\
\hline \multicolumn{2}{|c|}{ Mean corpuscular volume (f L) } & $88.13 \pm 7.5$ & $87.06 \pm 10.9$ & 0.637 & 0.525 \\
\hline \multicolumn{2}{|c|}{ Mean corpuscular $\mathrm{Hb}-(\mathrm{pg})$} & $28.50 \pm 2.8$ & $27.85 \pm 4.2$ & 1.013 & 0.313 \\
\hline \multicolumn{2}{|c|}{ Mean corpuscular Hb concentration (g/dL) } & $32.33 \pm 1.4$ & $31.83 \pm 1.8$ & 1.708 & 0.090 \\
\hline \multicolumn{2}{|c|}{ Red cell distribution width - S D (\%) } & $44.37 \pm 5.6$ & $45.61 \pm 6.8$ & -1.23 & 0.263 \\
\hline \multicolumn{2}{|c|}{ R D W - C V (Coefficient of variation) (\%) } & $14.12 \pm 1.3$ & $15.62 \pm 6.5$ & -1.788 & 0.076 \\
\hline Age (years) & $54.7 \pm 9.09$ & $55.7 \pm 11.06$ & $54.46 \pm 8.6$ & 0.169 & 0.844 \\
\hline WBC $\left(10^{3} / \mu \mathrm{L}\right)$ & $12.01 \pm 4.34$ & $11.1 \pm 4.34$ & $9.29 \pm 3.8$ & 5.810 & $0.004^{*}$ \\
\hline $\operatorname{RBC}\left(10^{5} \mu \mathrm{L}\right.$ & $4.97 \pm 0.7$ & $4.86 \pm 0.4$ & $4.85 \pm 0.7$ & 0.430 & 0.651 \\
\hline $\mathrm{Hb}(\mathrm{g} \%)$ & $13.5 \pm 2.9$ & $14.06 \pm 1.36$ & $13.42 \pm 2.5$ & 0.573 & 0.564 \\
\hline Het (\%) & $43.2 \pm 5.66$ & $43 \pm 3.79$ & $41.98 \pm 6.9$ & 0.612 & 0.544 \\
\hline MCV (f L) & $87.6 \pm 7.46$ & $88.9 \pm 7.84$ & $87.06 \pm 10.9$ & 0.315 & 0.705 \\
\hline $\mathrm{MCH}(\mathrm{pg})$ & $28.14 \pm 2.84$ & $29.09 \pm 2.91$ & $27.85 \pm 4.2$ & 1.016 & 0.365 \\
\hline
\end{tabular}

\section{DISCUSSION}

In our study, we found that there was no association between RDW, Hct, and other RBC indices among CAD and controls. There was no association between RDW, Hct, and other RBC indices among AMI, SCAD, and controls.

Several previous studies have shown that increased Hct and other RBC indices have been associated to CAD and mortality. Recently, many articles have established association between RDW and CADs. RDW represents the circulating size variance of the RBC. It is based on the width of the RBC distribution volume curve with larger values which imply higher variance. .,9 $^{8}$ RDW usually reduces under useless red cell production conditions( such as anemia, B12 or folate insufficiency and hemoglobinopathies), reduced red cell destruction( such as hemolysis) and blood transfusion. ${ }^{10,11}$ Previous RDW analyses were mostly conducted in cohorts or randomly assigned trials with significant CAD patients. ${ }^{12,13,14}$ Even though these research showed that RDW was highly related to CAD incidents and allcause mortality, information from the Third National Health and Nutrition Examination Survey( NHANES III) revealed that RDW significantly predicted deaths from CAD, cancer, chronic disease of the lower respiratory tract and other causes except external causes( e.g. traffic accidents). ${ }^{15,16}$ But there are very few case-control studies regarding association of increase in RDW and CAD in India. Since RDW is correlated with multiple death causes, it is believable that RDW is 
affected by various diseases and is an integrative receptor of dysfunctionality and abnormality in physiological systems.

The use of RDW beyond its use in the study of some anemia should be considered. Some studies show that RDW can be a useful source of information for Celiac disease, colon cancer, and ACS in emergency departments. ${ }^{17,18,19}$ Contrast to these studies, we did not observe association between RDW, Hct, and other RBC indices with CAD. This may be because of relatively low sample size due to the study design, attempting to limit the influence of several covariables. But again, it is not known and should be investigated despite the fact that the RDW improves the lifestyle conditions of each myocardial infarction or congestive heart failure.

\section{CONCLUSION}

Our strength of study was compared to other retrospective evaluations of laboratory data, the time between blood sampling and AMI was specified. In our understanding, we are the first to study this article in the Pakistani population, which means within 6 hours of heartbreak. Therefore, this study is an evaluation study that can be re-used to restore the focus between RDW and Coronary Artery Disease.

\section{ACKNOWLEDGEMENT}

We acknowledge Mr. Farooq Ahmed Mangnejo s/o Imam Bux for his technical help in the manuscript.

\section{Copyright@ 25 May, 2019.}

\section{REFERENCES}

1. Romero Artaza J, Carbia CD, Ceballo MF, Díaz NB. Red cell distribution width (RDW): Its use in the characterization of microcytic and hypochromic anemias. Medicina (B Aires) 1999; 59:17-22.

2. Tefferi A, Hanson CA, Inwards DJ. How to interpret and pursue an abnormal complete blood cell count in adults. Mayo Clin Proc 2005; 80:923-36.

3. Felker GM, Allen LA, Pocock SJ, Shaw LK, McMurray JJ, Pfeffer MA, et al. CHARM Investigators. Red cell distribution width as a novel prognostic marker in heart failure: Data from the CHARM Program and the Duke Databank. J Am Coll Cardiol 2007; 50:40-7.
4. Tonelli M, Sacks F, Arnold M, Moye L, Davis B, Pfeffer M. For the Cholesterol and Recurrent Events (CARE) Trial Investigators. Relation between red blood cell distribution width and cardiovascular event rate in people with coronary disease. Circulation 2008; 117:163-8.

5. Toss F, Nordström A, Nordström P. Association between hematocrit in late adolescence and subsequent myocardial infarction in Swedish men. Int $\mathrm{J}$ Cardiol 2013; 168:3588-93.

6. Greenberg G, Assali A, Vaknin-Assa H, Brosh D, Teplitsky I, Fuchs S, et al. Hematocrit level as a marker of outcome in ST-segment elevation myocardial infarction. Am J Cardiol 2010; 105:435-40.

7. Ennezat PV, Maréchaux S, Pinçon C, Finzi J, Barrailler $\mathrm{S}$, Bouabdallaoui N, et al. Anaemia to predict outcome in patients with acute coronary syndromes. Arch Cardiovasc Dis 2013; 106:357-65.

8. Uyarel H, Ergelen M, Cicek G, Kaya MG, Ayhan E, Turkkan C, et al. Red cell distribution width as a novel prognostic marker in patients undergoing primary angioplasty for acute myocardial infarction. Coron Artery Dis 2011; 22:138-44.

9. Zalawadiya SK, Veeranna V, Niraj A, Pradhan J, Afonso $\mathrm{L}$. Red cell distribution width and risk of coronary heart disease events. Am J Cardiol 2010; 106:988-93.

10. Förhécz Z, Gombos T, Borgulya G, Pozsonyi Z, Prohászka $Z$, Jánoskuti L. Red cell distribution width in heart failure: Predictionof clinical events and relationship with markers of ineffective erythropoiesis, inflammation, renal function, and nutritional state. Am Heart J 2010; 158:659-66.

11. Chen PC, Sung FC, Chien KL, Hsu HC, Su TC, Lee YT. Red blood cell distribution width and risk of cardiovascular events and mortality in a community cohort in Taiwan. Am J Epidemiol 2010; 171:214-20.

12. Anderson JL, Ronnow BS, Horne BD, Carlquist JF, May $H T$, Bair TL, et al. Usefulness of a complete blood count derived risk score to predict incident mortality in patients with suspected cardiovascular disease. Am J Cardiol 2007; 99:169-74.

13. Ani C, Ovbiagele B. Elevated red blood cell distribution width predicts mortality in persons with known stroke. J Neurol Sci 2009; 277:103-8.

14. Cavusoglu E, Chopra V, Gupta A, Battala VR, Poludasu $\mathrm{S}$, Eng $\mathrm{C}$, et al. Relation between red blood cell distribution width (RDW) and all-cause mortality at two years in an unselected population referred for coronary angiography. Int J Cardiol 2010; 141:141-6. 
15. Patel KV, Ferrucci L, Ershler WB, Longo DL, Guralnik JM. Red blood cell distribution width and the risk of death in middle-aged and older adults. Arch Intern Med 2009; 169:515-23.

16. Perlstein TS, Weuve J, Pfeffer MA, Beckman JA. Red blood cell distribution width and mortality risk in a community-based prospective cohort. Arch Intern Med 2009; 169:588-94.

17. Lippi G, Filippozzi L, Montagnana M, Salvagno GL, Franchini M, Guidi GC, et al. Clinical usefulness of measuring red blood cell distribution width on admission in patients with acute coronary syndromes. Clin Chem Lab Med 2009; 47:353-7.
18. Sategna Guidetti C, Scaglione N, Martini S. Red cell distribution width as a marker of coeliac disease: $A$ prospective study. Eur J Gastroenterol Hepatol 2002; 14:177-81.

19. Spell DW, Jones DV Jr, Harper WF, David Bessman J. The value of a complete blood count in predicting cancer of the colon. Cancer Detect Prev 2004; 28:3742.

\begin{tabular}{|c|c|c|c|}
\hline \multicolumn{3}{|c}{ AUTHORSHIP AND CONTRIBUTION DECLARATION } \\
\hline Sr. \# & \multicolumn{1}{|c|}{ Author(s) Full Name } & \multicolumn{1}{|c|}{ Contribution to the paper } & Author(s) Signature \\
\hline 1 & Shahzeb Rasool Memon & $\begin{array}{l}\text { Study designing, sample } \\
\text { collection and article writing. } \\
\text { Study design, sample } \\
\text { collection. } \\
\text { Writing corrections, data } \\
\text { interpretation, corresponding }\end{array}$ & \\
\hline 4 & Gul Hassan Brohi & Fozia Rasool Memon & $\begin{array}{l}\text { author. } \\
\text { Statistical analysis and data } \\
\text { interpretaion. } \\
\text { Writing support, data } \\
\text { interpretaion. } \\
\text { Proof read. }\end{array}$ \\
\hline 6 & Samreen Memon & Shazia Begum Shahani \\
\hline
\end{tabular}

